\title{
Research on the Speech Authority of Chinese Culture in College English Teaching
}

Qiushuang Zhang ${ }^{*}$, Mengshi Du, Lihong Wang

Foreign Language College, North China Electric Power University (Baoding), Baoding, China DOI: $10.36348 /$ sijll.2019.v02i07.005 | Received: 20.09.2019 | Accepted: 27.09.2019 | Published: 30.09.2019

*Corresponding author: Qiushuang Zhang

\section{Abstract}

This research, based on the analysis of the themes in the college English textbooks and the analysis of the need of Chinese elements, combined with the quantitative discussion and analysis about the speech authority distribution in English textbooks which is acquired by questionnaire surveys, and by the discussion about the cultural orientation of students and the influence on their language-leaning and trans-cultural communication the speech authority distribution brings about, provides substantial support for college English teaching studies.

Keywords: English Textbooks; Chinese Elements; Questionnaires; Aphasia of Chinese Culture; Speech Authority.

Copyright @ 2019: This is an open-access article distributed under the terms of the Creative Commons Attribution license which permits unrestricted use, distribution, and reproduction in any medium for non-commercial use (NonCommercial, or CC-BY-NC) provided the original author and source are credited.

\section{INTRODUCTION}

Nowadays, college English teaching keeps up with the pace of globalization. As a world language, English functions as the carrier of culture transmission and ideologies. From the perspective "fostering the community of shared future for all mankind and the multicultural awareness [1]", the combined paradigm that multi-culture and multi-language coexist and merge each other becomes the new normalcy for context of contemporary use of English. From the culturalcognitive view, English-Learning on the one hand must express traditional Chinese culture, but on the other hand, it also need to project the contemporary basic conditions of China. Under that circumstance, propagating Chinese culture in English becomes an important approach for the spreading of Chinese culture. But the "aphasia of Chinese culture" is a big problem in the foreign language teaching area in China. For years the main work in the foreign language teaching area in China is the introduction of language teaching theories from abroad and the digestion and application of them [2], especially in the phase of basic foreign language education. Foreign language scholars constantly call for the construction of Chinese special foreign language teaching theories, the completion of the system of foreign language education and teaching, and the improvement of our teaching quality [3, 2, 4$6]$. This research provides the analysis of the phenomenon of Chinese culture deficiency in college English textbooks; at the same time, it discusses the methods for Chinese culture entering English classes, aiming at exloring new ways for the transmission of Chinese culture speech authority, at solving the problem of single-directional transmission of western culture in foreign language teaching practice, at fostering qualified English majors who can tell Chinese stories and convey Chinese culture in English and improving other non-English-major professionals.

\section{The Status Quo of Speech Authority in China and Abroad}

Foreign countries have earlier paid attention to the discourse power in English education and achieved certain results. There are 384 papers concerning this subject totally in Springer retrieval since 2001, among which, the papers concerning ESL in bilingual and multilingual education take up $99.2 \%$, for example, Fair Clough [7]'s "dialectic-relational" method, Van Dijk [8]'s "social-cognitive" method, etc; their focal points mainly include the speech authority in policies on bilingualism $[9,10]$ and the speech authority in school classes [11]. And these speech authority researches have certain positive effects on the western culture transmission.

There are not many empirical researches on the Chinese culture speech authority in English education, and mostly on the level of literature review. Researches on literature review develops on two aspects, first, on the phenomenon of "culture aphasia" $[12,13]$ and on the Chinese culture entering English- 
teaching classes; second, on the critical discourse analysis of English textbook texts, in order to reveal their cognitive orientation [14] or meaning construction functions [15]. But they are mainly on the level of retrospection and revelation in English teaching, without empirical systematic analysis and research from real teaching experience $[16,11]$.

\section{The Status Quo in College English Teaching The lack of Cultural Literacy}

In 1999, the idea of "cultural literacy" first comes out in College English syllabus (revised), but until the newly published College English teaching requirements [17], "Its concept of language and culture teaching is still stuck in the traditional mode of cultural exchange between China and the west, ignoring the fine traditional Chinese culture and the current socialism culture". As a carrier of culture, language shapes people's ideas and ways of thinking, and changes people's life styles. At the same time, it also highlights national culture and historical characteristics, and conveys the characteristics of social times. The arrival of globalization makes the exchanges between countries increasingly frequent. In the context of globalization, cross-cultural communication should be subjective and cross-referent. Chinese students have been learning English for years, but they have some communicational barriers in cross-cultural communication. The reason is that in English teaching people should choose language materials that students are interested in, which are healthy and original. Through systematic and guided learning of those materials, students will be triggered by multi-dimensional perceptions and experience of language; then they will acquire the ability of language perception, absorb language knowledge, at the same time strengthen their understanding of foreign language culture and improve their humanistic quality [18]. Taking the current college English textbooks as an example:

Table-1: Proportions in the current college English textbooks

\begin{tabular}{|l|l|l|}
\hline Names of textbooks & Proportion of foreign culture & Proportion of Chinese culture \\
\hline College English new edition & $98.5 \%$ & $1.5 \%$ \\
\hline New Horizon College English & $97.1 \%$ & $2.9 \%$ \\
\hline College English Intensive Reading & $98 \%$ & $2 \%$ \\
\hline
\end{tabular}

Those three kinds of college English textbooks are often marked with typical characteristics of British and American people in terms of content, thinking mode and customs. That Chinese mother language culture is in an awkward situation makes Chinese students cannot tell China's own story well. Thus not only will their speech authority becomes weaker and weaker on the international stage, but they will also be restricted in improving Chinese cultural literacy.

\section{Questionnaire Surveys on Cultural Literacy}

In this research, questionnaire surveys are conducted among some sophomore students in four universities, namely North China Electric Power University, Hebei University, Hebei Agricultural University and Hebei Finance University. Questionnaires are counted by SO JUMP, and the number of valid questionnaires is 1,250. The questionnaires are conducted on the following four topics.

\section{Question 1: which cultural elements are dominant in college English textbooks?}

According to the questionnaire, the culture of European and American countries accounts for $88.85 \%$ of the teaching materials, while that of Chinese culture accounts for $8.92 \%$. This reflects that students absorb more target language culture in college textbooks and less Chinese culture. Culture of Asian, African and Latin American countries involved in the study have even much lower proportions in textbooks due to their weak speech authority on the international stage.

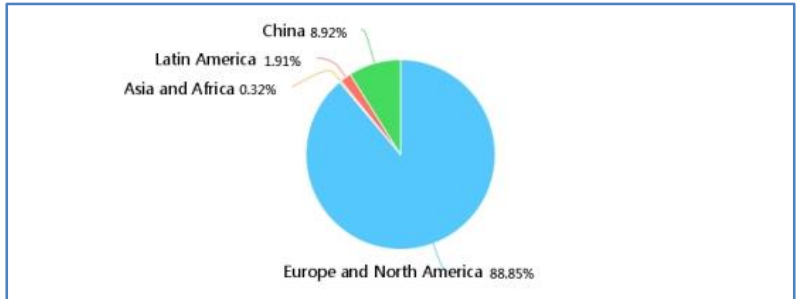

Fig-1: Proportions of cultural elements contained in college English textbooks

Question 2: "what aspects of western culture do college English textbooks reflect?"

According to the questionnaires, the proportion of custom and habit in European and American culture in college English textbooks takes up $78.03 \%$, which is much higher than that of political culture and religious culture. Because compared with political culture and religious culture, custom and habit culture is more tangible and closer to daily life, which for students is easier to absorb and accept. Moreover, custom culture is more vivid and interesting for students, while political culture and religious culture are relatively profound and difficult to understand.

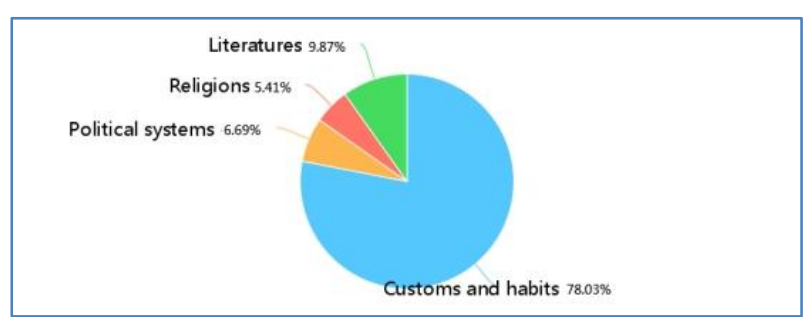

Fig-2: Aspects of western culture that college English textbooks reflect 


\section{Question 3 "How do you learn Chinese cultural elements in study?"}

For the question, 41.08 percent of the students say that they learn Chinese elements through the teachers' explanation, followed by English textbooks. Due to the lack of Chinese cultural elements in textbooks, teachers need to supplement relevant cultural contents and conduct comparative studies between Chinese and foreign cultures.

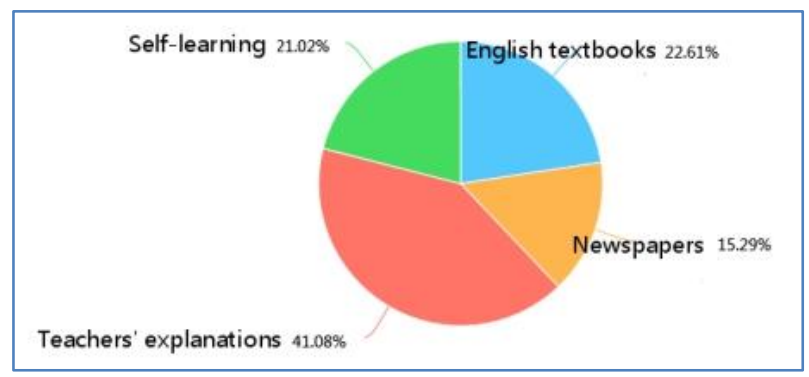

Fig-3: Ways of learning Chinese cultural elements in study

\section{Question 4 "What Chinese elements should be added to college English textbooks?"}

As for this question, $66.24 \%$ of the students think that Chinese customs and habits should be incorporated into college English textbooks and the proportion of Chinese food and clothing is very small, which reflects that students are interested in customs and habits, and materials related to Chinese customs and habits should be appropriately included in teaching. As more and more exchanges with foreign countries by the The Reform and Openning-up Policy, the proportion of Chinese cultural elements in college English textbooks should be increased, so as to improve the speech authority of Chinese culture and make it more powerful on the international stage.

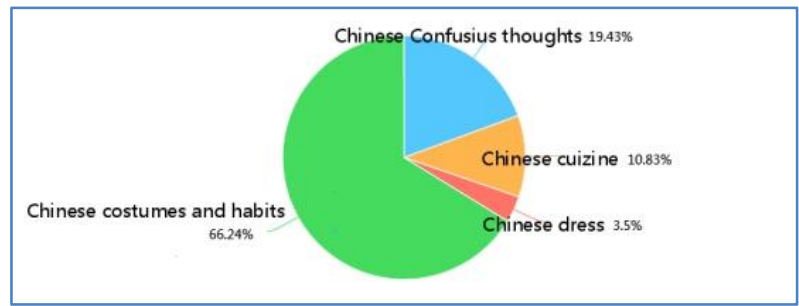

Fig-4: What Chinese elements should be added to college English textbooks?

According to the questionnaire survey, as the most fundamental reflection of the course content, the "Chinese culture aphasia" in college English textbook is quite serious. College English learners are still so immersed in "British and American culture" in a singledirectional way that they identify more with the culture of English-speaking countries than their own culture and Chinese students are lost in western culture, which makes them lack of initiative cultural communication and unable to spread effectively their own culture. Wang Shouren, a famous scholar, once pointed out "if Chinese scholars cannot make their voices heard and preach Chinese native culture to the world, the world will not hear the voices of Chinese elites. The so-called 'globalization' cannot become a dialogue in China, but a one-way input. Over time, the phenomenon of 'Chinese cultural aphasia' cannot be changed [19]'.

\section{The Exploratory Practice of Chinese Culture into College English Teaching}

The academic circle has been calling for that "we should integrate Chinese elements into English teaching materials", but there is no systematic research on "what English texts containing Chinese elements should be integrated?" and "how to integrate?". Meanwhile, Chinese text corpus is mainly about the construction of learner's English corpus and college English textbook corpus, and there is the lack of corpus related to English discourse that reflects Chinese culture and speech authority, which make the compilation of new textbooks reflecting the new era difficult. For the lack of Chinese culture in actual teaching, this research focuses on "what kind of Chinese culture should be integrated into college English teaching?" and the teaching effects after integration, and accumulates materials the future establishment of college English text corpus.

"Culture is the soul of a nation as well as its people. The culture of socialism with Chinese characteristics originates from the great traditional Chinese culture nurtured by the Chinese nation's fivethousand-year civilization, is merged in the revolutionary culture and advanced socialist culture created by the CPC leading the people in revolution, construction and reform, and is rooted in the great practice of socialism with Chinese characteristics[14].”. In the full report, we can clearly see that the socialism culture with Chinese characteristics includes the fine traditional Chinese culture, Chinese revolutionary culture and the advanced socialism culture. This report comprehensively summarizes the content of Chinese culture and points out the direction for the integration of Chinese culture into college English teaching. How to integrate these cultural elements into college English teaching is a problem that needs to be further studied now to improve the speech authority of Chinese culture. The essential attribute and goal of foreign language education should be to help students understand the world culture and Chinese culture, so as to improve students' humanistic quality and cultivate their humanistic spirit $[20,18]$. The humanity of foreign language courses $[21,22]$, should be "aiming high" by selecting high-quality language materials with humanistic value as the content of foreign language teaching $[18,23,24]$.

In this research, a comparative study is conducted between the experimental group and the control group to explore the integration of Chinese culture in teaching. Finally, the results of middle and final exams, cet-4 translation, self-presentation and talent competition and so on are expected to measure 
whether students have made overall progress in the process of learning Chinese culture.

\section{Videos of Chinese Cultural Elements}

After the in-depth study of Xi Jinping's speech at the 19th National Congress of the Communist Party of China, three Chinese cultural elements are integrated into actual teaching, among which high-value language materials are selected as teaching materials needed by the experimental group of students and transferred into video materials and written materials. These Chinese cultural materials include the following ones.

Table-2: Contents of videos of Chinese Cultural Elements

\begin{tabular}{|l|l|}
\hline $\begin{array}{l}\text { Chinese cultural } \\
\text { elements }\end{array}$ & Contents of culture \\
\hline $\begin{array}{l}\text { Chinese Traditional } \\
\text { Culture }\end{array}$ & $\begin{array}{l}\text { Spring Festival, Lantern Festival, Tomb-Sweeping Day, Dragon Boat Festival, } \\
\text { Chinese Valentine's day, Mid-Autumn Festival, National Day, Double Ninth } \\
\text { Festival }\end{array}$ \\
\hline Chinese great culture & $\begin{array}{l}\text { Beijing Opera, calligraphy, tea, paper making, gunpowder, printing, compass, } \\
\text { silk road, architectural differences between north and south (siheyuan, hui- } \\
\text { style architecture) }\end{array}$ \\
\hline $\begin{array}{l}\text { Chinese } \\
\text { revolutionary culture }\end{array}$ & $\begin{array}{l}\text { Revolutionary figures (Mao Zedong, Zhu De, Zhou Enlai) and revolutionary } \\
\text { deeds, etc. }\end{array}$ \\
\hline
\end{tabular}

There are preliminarily 20 micro-videos and written materials about Chinese culture, and in-depth discussion on Chinese traditional culture, fine culture and revolutionary culture is conducted in this research. The micro-videos are applied in actual teaching in the experimental group, and then these videos are put on internet so that the control group can learn them, in order that both the experimental group and the control group can learn the same contents.

\section{The Translation Part in the Past Exam Papers of CET-4}

Since December 2003, the translation part in CET-4 has changed from single Chinese sentence translation to Chinese paragraph translation, which is about Chinese culture, accounting for $15 \%$ of score in CET-4. The lack of Chinese culture in college English textbooks has caused some difficulties for non-English major students. Only under the guidance of teachers or self-learning can students become quite easy in translation of Chinese part in CET-4. This study analyzes the types of translation part in CET-4 in the past five years and applies them to the actual teaching in the experimental group.

Table-3: Types of translation part in CET-4 in the past five years

\begin{tabular}{|l|l|l|l|}
\hline Years of CET-4 & Content of CET-4 & Tea \\
\hline 2013.12 & Chinese cuisine & Chinese knot & $\begin{array}{l}\text { Nuclear energy in } \\
\text { China }\end{array}$ \\
\hline 2014.6 & Education equality & Education workers & Holiday economy \\
\hline 2014.12 & Young tourists & Panda & Expressage in China \\
\hline 2015.6 & Rice & China & Lecture in Chinese \\
\hline 2015.12 & Parents and children & Lijiang, Yunnan & Wu county \\
\hline 2016.6 & Chinese kungfu & Weifang kite & Chinese white \\
\hline 2016.12 & Chinese red & Chinese yellow & Zhu River \\
\hline 2017.6 & Yellow River & Long River & Mount Huang \\
\hline 2017.12 & Mount Tai & Mount Hua & \\
\hline
\end{tabular}

It can be seen from the analysis of the translation part in CET-4 that Chinese culture has appeared in the student tests. And the current course content has not caught up with it, so it is imperative to supplement Chinese cultural knowledge. There are enough supplements of Chinese culture translation materials in the experimental group in teaching such as previous CET-4 exams and the Chinese culture translation knowledge is explained. All materials used in the experimental group are distributed to the students in control group for their learning.

\section{Comparison between Chinese and Foreign Cultures}

In the history of all countries in the world, how were countries developing during a certain period? What events took place abroad during a certain period? What kind of historical figures were there? Who are the pop stars, movie stars and athletes nowadays? These questions attract students' interests. According to the English course of each unit, the team members make targeted supplementary explanation of relevant Chinese materials, which reflect the originality of English and guarantee the value and humanity of materials. For example, Benjamin Franklin (1706-1790) is one of the founding fathers of the United States and he is a famous 
statesman, scientist, diplomat and inventor. Franklin's period is that of Kangxi's period in Qing dynasty in China, at which time, Chinese culture was weak and stuck in its own way. The "sea ban" policy issued by Kangxi shackled China from exchanging with foreign countries and China was in a very unfavorable state in the fields of economy, diplomacy and culture, while foreign technological inventions and navigation were flourishing and went far beyond China. Another example, the Bible, which records that ancient Hebrew people lived at the junction of Asia, Africa and Europe, is the crystallization of collective wisdom over thousands of years, and also the classic of both Judaism and Christianity. It shapes the cultural and historical traditions and characteristics of the western society which has lasted for two thousand years, and it has also influenced the historical development and culture process of other vast areas of the world. Confucianism and the doctrines of Confucius and Mencius are also the treasures of Chinese culture and the deposits of Chinese history, which are worth learning for future generations. In actual teaching, Chinese and foreign cultural knowledge should be explained and compared and the proportion of Chinese cultural elements in college English textbooks should be increased on purpose in order to promote the students' learning of Chinese cultural knowledge. The relevant materials collected by the research team are explained in the experimental group and sent to the control group for learning.

After learning and trained for getting hold of Chinese culture for almost a year, the students in the experimental group have made great progress in the mid-term examination, final examination and CET-4, especially in the translation part. Relevant performance analysis will be further demonstrated in the following. Students in the experimental group then exhibit Chinese culture elements incisively and vividly in English activities such as self-presentations and talent competitions organized by universities or their departments.

The exploration of the practice of teaching Chinese culture in college English teaching is still in its infancy, and there is no experience to follow. This research tries to arouse people's attention to Chinese elements in western culture from a whole new perspective, so that Chinese students can play a greater role in the international arena. This research will continue to use English texts with Chinese elements and speech authority as corpus to construct "Chinese culturae text corpus of college English" in relevant researches in the future, so as to provide text sources for the compilation of relevant college English textbooks and effectively change the problem of the lack of Chinese elements.

\section{CONCLUSION}

Since China's speech authority has become the focus of academic research, the relevant researches on the international transmission of China's voice are mainly concentrated in the fields of Marxism, international relations and cross-cultural communication. The research on Chinese culture in college English teaching both for English majors and non-major students is basically limited to literature research, without relevant empirical research or textual corpus construction in this field. This research, taking the English textbooks as the important carrier of Chinese culture for transmission, focuses on solving the problem of single-directional transmission of western culture in foreign language teaching, and tries to cultivate English major talents who can tell Chinese stories and convey Chinese culture in English and improve the ability of non-English majors, in order to explore new methods to spread the speech authority of Chinese culture. However, how too systematically and scientifically construct "Chinese cultural texts corpus of college English" is expected to be made further breakthroughs, so as to take the construction of Chinese culture and the cross-cultural communication between China and the west to a higher level.

\section{REFERENCES}

1. The Ministry of Education of the People's Republic of China. (Ed.). (2018). National English curriculum standards for general high school. Beijing, China: People's Education Press.

2. Shu, D. (2005). Calling for foreign language teaching theories with Chinese characteristics. Foreign Language World, 6: 2-7.

3. Dai, W. (2001). To build a "through-train" system of English teaching with Chinese characteristics. Foreign Language Teaching and Research, 5: 322327.

4. Shu, D. (2017). The profound practical basis of foreign language teaching theory with Chinese characteristics -- Mr. Lu Gusun's foreign language teaching concept and proposition. Foreign Language World, 1: 15-21.

5. Zhang, W., \& Zhu, H. (2002). Chinese culture in college English teaching. Research on Education Tsinghua University, (S1): 35

6. Xv, Y. (2011). Some thoughts on constructing foreign language teaching theory in China. Computer-assisted Foreign Language Education, 6: 24-31.

7. Fairclough, N. (Ed.). (2001). In language and power. London, UK: Longman, 2001:91-116.

8. Van Dijk, T. A. (2009). Society and discourse: how social context influence text and talk. London, UK: Cambridge University Press.

9. Pennycook, A. D. (Ed.). (1998). English and the discourses of colonialism. London, UK: Routledge.

10. Seargeant, P. (2008). Ideologies of English in Japan: the perspective of policy and pedagogy. Language Policy, 7(2): 121-142.

11. Tang, L. (2009). Critical discourse analysis on the interpretation of cultural hegemony of English learners, 
PLA Foreign Language University, 32(4): 47-51.

12. Cong, C. (2001, October 19). "Chinese culture aphasia" : defects of English teaching in China. Guangming Daily.

13. Deng, W., \& Ao. F. (2005). Analysis of Chinese culture aphasia of English majors. Journal of Bingtuan Education Institute, (4): 58-61.

14. Xin, B. (2007). The social and cognitive orientation of critical discourse analysis. Foreign Languages Research, 6: 19-24.

15. Wang, Y., \& Wang, W. (2013). Critical analysis of text in English textbooks. Foreign Languages Research, 5: 66-69.

16. Lin, J. (2008). Critical discourse analysis and its revelations for foreign language teaching. Heilongjiang Researches on Higher Education, 7: 176-179.

17. Department of Higher Education, Ministry of Education. (2007). College English teaching requirements. Shanghai, China: Shanghai Foreign Language Education Press.

18. Han, B. (2007). The approaches and methods of basic English quality education in China [Report]. Application Report on Key Projects of The Ministry of Education in The Eleventh Five-Year Plan for National Education Science.
19. Zeng, M. (2015). Cultural security research in foreign language education [Academic dissertation]. Wuhan, China: Central China Normal University.

20. Cheng, B., \& Liu, R. (2008). Review and reflection on English education in China's elementary education stage (I) - policy and purpose. Foreign Language Teaching and Research, (2): 150-155.

21. The Ministry of Education of the People's Republic of China. (Ed.). English curriculum standard for compulsory education. Beijing, China: Beijing Normal University Publishing Group.

22. Cheng, B. (2018). The core concept of overall foreign language education. Foreign Language Education, (2): 52-56.

23. Shu, D. (2012). The exploration of foreign language teaching mode with Chinese characteristics -- an experiment of foreign language teaching reform in the basic stage. Foreign Languages and Their Teaching, (5): 1-5.

24. The Ministry of Education of the People's Republic of China. (Ed.). English Curriculum Standards for General High School of Full-Time Compulsory Education. Beijing, China: Beijing Normal University Publishing Group. 